\title{
Özel gereksinimli kahramanı bulunan resimli çocuk kitaplarının incelenmesi*
}

\section{An investigation of illustrated children's books that focus on special needs}

\author{
Sima Kırkgöz ${ }^{1}$, İbrahim Halil Diken ${ }^{2}$
}

Makale Geçmişi

Geliş : 26 Temmuz 2019

Düzeltme : 08 Eylül 2019

Kabul : 10 Eylül 2019

Çevrimiçi : 17 Eylül 2019

\section{Makale Türü}

Araştrma Makalesi

\begin{abstract}
Öz: Bu araştırmanın amacı, içinde özel gereksinimli karakteri olan 0-8 yas, arası çocuk kitaplarının iç ve dış yapı özelliklerinin bir çocuk kitabının taşıması gereken çocuk edebiyatı ölçütlerini ne derece karşıladığını belirlemeye çalışmaktır. Çalışmada tarama modeli kullanılmışır. Internet üzerinden taranan kataloglarda ölçüt örneklem yöntemi kullanılmıştır. Araştırmanın örneklemini 0-8 yas, arası çocuklar için yazılmış 17 kitap içerisinde 27 hikaye oluşturmaktadır. Araştırma kapsamında, kitapların iç ve diş yapı özelliklerini değerlendiren 77 sorudan oluşan iki veri toplama aracı geliştirilmiş ve özel eğitim alanında uzman bir akademisyenin görüşleri alınarak gerekli düzenlemeler yapilmıştır. Uygulama güvenilirliğini değerlendirmek amacıyla puanlayıcılar arası kayıt güvenilirliği yöntemi kullanılmıştır. İnceleme sonunda diş, yapı özelliklerinden 15 madde yeterli, 1 madde kısmen yeterli, 15 madde yetersiz düzeyde bulunmuştur. İçyapı özelliklerinden 25 madde yeterli, 2 madde kısmen yeterli ve 19 madde yetersiz düzeyde bulunmuştur. Çalışmada ulaşılan bulgulardan yola çıkılarak uygulamaya yönelik öneriler sunulmaktadır.
\end{abstract}

Anahtar Kelimeler: Çocuk Edebiyatı; Dış Yapı; İç Yapı; Özel Gereksinim

Abstract: The purpose of this study was to determine the special needs characteristics in the content and layout features of children's books. A descriptive survey method was employed. The sample comprised 17 illustrated story books, which contained 27 stories written for children aged eight years and younger. The researcher developed a data collection instrument that comprised two sections. The instrument evaluated the content and layout features of the books with 77 questions. Furthermore, the expertise of professors engaged in special education was obtained. The interrater reliability method was employed to assess the reliability of the instrument. The results revealed that of the items that assessed layout, 15 were sufficient, one was partially sufficient, and 15 items were insufficient. Furthermore, of the items that evaluated content, 25 were sufficient, two were partially sufficient, and 19 were insufficient. Recommendations for practice are made.

Keywords: Children’s Literature; Layout Criteria; Content Criteria; Special Needs

\footnotetext{
Başlıca Yazar: Sima Kırkgöz

${ }^{*}$ Bu çalışma 27. Ulusal Özel Eğitim Kongresi’nde sözlü bildiri olarak sunulmuştur.

${ }^{1}$ Anadolu Üniversitesi, Eğitim Bilimleri Enstitüsü, Zihin Engelliler Öğretmenliği Bölümü, skirkgoz@anadolu.edu.tr, ORCID: https://orcid.org/0000-0003-0290-1024

$\frac{1}{2}$ Anadolu Üniversitesi, Engelliler Araştırma Enstitüsü, ibrahimhalildiken@gmail.com, ORCID: https://orcid.org/0000-0002-5761-2900
} 


\section{SUMMARY}

\section{Introduction}

Positive peer relationships are important for children with disabilities and for those with normal development. However, studies on the social acceptance of children with disabilities have revealed that normal developing children do not prefer their peers with disabilities. Children with normal development may lack practice in inclusion and/or be unable to recognize their peers' special needs properly. Children who have never met children with disabilities may develop an inclusive perspective to differences through children's literature. Children's literature has an important role to play in this recognition and integration. The purpose of this study was to determine to what extent the content and layout features of children's books for those under the age of eight years on special needs meet the criteria for children's literature. Consequently, the following questions were asked:

1. To what extent do children's books, which convey disabilities, satisfy layout (formal) criteria?

2. To what extent do children's books, which convey disabilities, satisfy content (contextual) criteria? Positive peer relationships are important for children with disabilities as well as children for normal development; however when studies of social acceptance of children with disabilities are viewed, it is seen

\section{Method}

The descriptive survey method was employed in this study. In the survey method, the object, person, or case is defined as they are or the event is within their own conditions (Karasar, 1998). More than 5000 books in children's book catalogs and at children's book publishers were scanned by employing keywords on the Internet. The criteria sampling method was from non-probability sampling methods was used. Accordingly, 27 stories formed the sample. The researcher developed a data collection instrument, which comprised 77 questions, by scanning books, and publications related to children's literature. Subsequently, the opinion of an academic who was a specialist in special education on the data collection instrument was considered. The data collection instrument comprised two sections: The first section included 31 questions that evaluated layout (formal) criteria and the second section included 46 questions that evaluated content (contextual) criteria. This instrument was used to evaluate 27 children's stories. Scores of three, two, and one were used to indicate if the items were sufficient, partially sufficient, or insufficient. Thereafter, the range of maximum and minimum scores were obtained, and divided into three equal parts. Accordingly, the frequency (f), percentage (\%), and average $(\mathrm{X})$ of the obtained data were calculated. Data to assess the reliability were collected by three special education teachers in 30\% ( $\mathrm{f}=8)$ of the sample. The criteria that a child's books should possess were explained to the teachers before credibility data were collected. The results revealed that the similarity found in evaluation of the books was $95.3 \%$.

\section{Results}

It appears that most books often address physical disabilities. The sample comprised nine stories about physical disabilities;; seven that did not specify the disability; three about either sense or behavior disorders 
including Tourette syndrome and obsessive compulsive disorder, respectively; three about hearing disabilities; two about visual disabilities; one about a learning disability, more specifically, dyslexia; one about Down syndrome; and one about autism.

The items that were evaluated as insufficient from the perspective of layout criteria included: Pages can be cleaned $(1,67)$; book cover is compatible with the subject $(2,19)$; the picture on the cover is also in the book $(2,22)$; a picture can be found on the sub-title of the book $(1,22)$; the title of the book is on the front cover $(1,27)$; the age group for which it is intended is on the front cover $(1,59)$; information not on the front cover is found on the inner cover $(1,22)$; reporting to printing number $(2,04)$; indicating the price of the book on the back cover (1.89); finding a dictionary in the book $(1,00)$, information about authors $(2,22)$; listing other works by the author $(1,96)$; listing other works of the publisher $(1,59)$; a linguist's study of the text; $(1,30)$; and a field specialist's study of the text $(1,22)$. The items on the criteria of the content that were deemed to be insufficient included: Reporting time in the text $(1,67)$; theme and topic support one another $(2,22)$; explanation of special needs $(1,89)$; correct use of terminology for special needs $(1,85)$; an introduction of the particular type of need $(1,70)$; making inferences to improve the social integration of individuals with disabilities (2,00); imparting positive attitudes toward individuals with disabilities $(2,07)$; good planning of flow of book $(2,19)$; explanation of the meanings of unknown words on the same page $(1,00)$; sentences that consist of a single subject and predicate $(1,89)$; alliteration $(1,37)$; length of paragraphs that are appropriate for age group $(2,00)$; absence of inverted sentences $(1,56)$; the book encourages the reader to read another book (2,22); the pictures are in the foreground $(2,19)$; suitable ratio of image-font on pages $(1,96)$; the pictures complement the text $(2,04)$; the text that explains the pictures are descriptive and interpretative $(1,96)$; and attention to detail in pictures $(2,07)$.

\section{Conclusion and Discussion}

Based on the findings, the following suggestions are made to authors and publishers. Common criteria can be established with the consensus of the author, publisher, and relevant experts on children's books. These criteria should meet quality standards and serve as a determinant for children's literature so as to produce better books. Most of the questions in the data collection instrument that related to special needs were evaluated as insufficient. It is imperative that books enjoy literary success and introduce special needs in an appropriate way. It may be beneficial for specialists in education and in subjects that are sensitive such as special needs to examine and develop books. 


\section{GİRIŞ̧}

Akranlar tarafindan kabul görme ve olumlu akran ilişkileri kurma, tipik gelişim gösteren çocuklar kadar özel gereksinimi olan çocuklar için de önemlidir; fakat özel gereksinimi olan çocukların kaynaştırma programlarındaki sosyal kabulleriyle ilgili yapılan çalısmalar incelendiğinde, genel olarak bu çocukların tipik gelissim gösteren akranları tarafindan tercih edilmediği görülmektedir (Çuhaloğlu-İmrak \& Sığırtmaç, 2011; Eratay \& Sazak-Pınar, 2006; Karadağ, Yıldız-Demirtaş \& Girli, 2014; Lausley \& Heflin, 2000). Bunun nedeni sınırlı iletişim becerilerine sahip özel gereksinimli çocukların kaynaştırılması konusundaki uygulama yetersizlikleri olabileceği gibi tipik gelişim gösteren çocukların, akranlarının özel gereksinimini tam olarak tanımamaları olabilir.

Duygu ve düşüncelerin yeterince eğitilmediği toplumlarda kişiler arası ilişkileri belirleyen güç, şiddet olur (Sever, 2002). Bu nedenle özel gereksinimi olan çocukların sosyal ve akademik hayatta toplumla bütünleşmesini sağlamak için çocukların birbirileriyle etkileşime girdiği ortamlarda bireysel farklılıklara dikkat çekerek iletişim, arkadaşlık ve işbirliği becerilerini arttırmayı sağlayacak stratejiler geliştirilmesi gerekmektedir (Locke, Ishijima, Kasari \& London, 2010). Bu amaca hizmet edebilecek yollardan biri de çocuk kitapları ile farkındalık oluşturmak olabilir. Zengin görsel ve dilsel uyaranlara sahip çocuk kitapları, çocukların bulundukları çevrelerde görüp yaşayamayacakları şeyleri tecrübe etmelerini sağlar. Hayatında hiç özel gereksinimi olan bireyle karşılaşmamış veya kendisine bu durum tanıtılmamış olan çocuk, bu alanda yazılmış bir çocuk edebiyatı eseri sayesinde farklılıklara dışlayıcı değil, dahil edici bir bakış açısı geliştirebilir. Çocuk edebiyatı bu köprüyü kurmada ve ön yargılar ile bilinmezlikleri en aza indirerek bütünleşmeyi sağlamada önemli bir yere sahiptir. Bu amacı edebi ölçütlerden ödün vermeden gerçekleştiren eserler, ideal olan eserlerdir (Gürdal-Ünal, 2011).

20. yüzyılın başında gelişmeye başlayan çocuk edebiyatının çocuklara değer ve tutum kazandırma konularında önemli işlevi vardır (Karatay, 2011). Çocuklar için hazırlanan kitaplar "çocuğa görelilik" ilkesini yansıtmalıdır. Onun içindir ki yepyeni bir edebiyat türü doğmuştur: Çocuk edebiyatı (Oğuzkan, 1997). Çocuk edebiyatı; 17. yüzyıldan itibaren basılı kültürün ayrı bir parçası olarak sunulmaya başlanan, hitap ettiği doğum ile ergenlik arasındaki yaş aralı̆̆ının dil ve anlama seviyesine uygun olarak ilgi çekici bir şekilde hazırlanan ve yazılı/görsel iletileri kullanan pek çok sanatsal türü içinde barındıran ürünlerin genel adıdır (Grenby, 2008; Lynch-Brown \& Tomlinson, 1998; Sever, 2002). Çocuk gelişiminde sanatın eğitsel işlevinden faydalanabilmek için sanat yoluyla eğitime erken yaşlarda başlamak gerekir (Sever, 2002). Çocukluk, aynı zamanda kişilik oluşumundaki en önemli evredir. Bu dönemde oluşacak tutumların hayat boyu devam etme olasıllğı yüksektir.

Çocuk edebiyatı ürünü olan resimli çocuk kitaplarının özel gereksinimli olma durumunu işlemesi 
ile özellikle okul öncesi dönemde, ele alınan konunun imgeleri zihinde kavramsallaştırılır, metnin iletileri görsel olarak tamamlanır ve çocuğun günlük hayatında karşılaşabileceği özel gereksinimi olan bireye yönelik pek çok özelliği zihninde canlandırma firsatı sağlar (Külük, 2013). Çocuklar, kendileri için hazırlanmış içinde özel gereksinimli kahramanı olan kitaplarla karşılaştıkça bu alanda yaşantı sağlamış ve akranlarıyla bütünleşmeye yönelik tutum geliştirmiş olurlar. Çocuğa ulaşabilen bir edebiyat ürünü oluşturmak çocuğa dışarıdan bakarak gerçekleşmez. Yazarın çocuk gerçekliğini yakalayabilecek yetkinlikte olması gerekir (Lynch-Brown \& Tomlinson, 1998). Nitelikli bir çocuk edebiyatı, anlamsal ve estetik boyutlar üzerinde yoğunlaşarak şekil almalıdır. Okumaları anlamlı hale getirebilmek için söz konusu ayrıntılara hakim olmak büyük önem taşır (Çiftçi, 2013). Bu nedenle aşağıda çocuk edebiyatıyla ilgili kitaplar ve yayınlardaki bilgiler ışı̆̆ında bir çocuk kitabında bulunması gereken özellikler derlenmiştir.

\section{Çocuk Kitaplarında Bulunması Gereken Dış Yapı (Biçim) Kriterleri}

Boyut. Kitabın boyutları kitaplık düzenlemesine ve kolay taşımaya uygun olan 16x23 cm boyutlarında olmalıdır (Sever, Adıgüzel, Dilidüzgün \& Öztürk, 2013). Kucağa sığabilecek olması da ölçü olarak kabul edilebilir (Turla \& Tür, 1999). Kullanılan yaygın şekiller dikdörtgen ve karedir (Çakmak-Güleç \& Geçel, 2006; Oğuzkan, 1997).

Kağıt. Pürüzlü, parlak ve ince kağıt algılamayı güçleştirir (Demirel, Çeçen, Seven, Tozlu \& Uludağ, 2010). Kuşe kağıt gözü yorar ve ekonomik değildir; pelur ve gazete kağıdı da kullanılmaması gereken kağıt türleridir (Çakmak-Güleç \& Geçel, 2006). Sayfalar; 1şı̆̆1 yansıtmayan, mat, kağıdın arkasından görünmez, dayanıklı birinci veya ikinci hamur olmalıdır (Sever vd., 2013). Çocuklar kitaba bir oyuncakmışçasına sahip olmak isterler. Bu nedenle kapakları ve ciltleri sağlam olmalıdır (Kibris, 2000).

Düzen. Çocuklar öncelikle kitabın kapağıyla karşılaşırlar. Bu nedenle kapağın ilgi çekici olması önemlidir (Demirel vd., 2010). Sayfa ve kapak düzeni hem çocukların kitaba olan olumlu duyuşsal davranışlar kazanmalarını hem de estetik algı geliştirmelerini sağlayacağı için grafik sanatçılarının bu aşamada görev alması gerekir (Sever vd., 2013).

Yazı. Sayfalardaki boşluk oranı yaş küçüldükçe arttırılmalıdır. Yazı boyutu da boşluk oranlarıyla uyumlu olup okul öncesi dönemde en az 2.6 mm. (14 punto) olmalıdır (Demirel vd., 2010). Sayfada bulunan tüm öğeler uyumlu olmalıdır . Bunun nedeni göze hoş gelen bir bütünlüğün okuma kolaylığı sağlamasıdır.

Künye Bilgileri. Kitapta künye bilgileri, içindekiler, sözlük gibi kılavuz bölümleri yer almalı; yayınevi ve yazarın diğer yapıtları hakkında okuyucu bilgilendirilmelidir (Demircan, 2006). 


\section{Çocuk Kitaplarında Bulunması Gereken İç Yapı (İçerik) Kriterleri}

Dil ve Üslup. Metinler anadilin anlatım gücünü ve ahengini yansıtmalıdır (Sever, 2002). Özellikle okul öncesi döneme hitap eden çocuk kitapları daha çok yetişkinler tarafından çocuklara okunduğu için metni sesli olarak aktarırken dilin güzelliğinin duyumsanmasına dikkat edilmelidir. Olaylar gereksiz ayrıntılardan arındırılmalı; kısa ve anlaşılır bir olay kurgusuna sahip olmalıdır. Anlatımlarda mantıksal hatalar yapılmamalıdır (Sever vd., 2013). Bu dönemde ortalama beş-altı sözcükten oluşan ve içinde tek özne-yüklem bulunan cümleler kurulmalıdır (Çakmak-Güleç \& Geçel, 2006). Anlatımda sadeliğe dikkat edilmeli, yöresel ve çevresel ağızlardan kaçınılmalıdır (Oğuzkan, 1997). Eğer çocuk metinde bulunan bir kelimeye aşina değilse ve kelime söylendiği gibi açıklanmıyorsa bu durum açıkça bir problemdir (Çakmak-Güleç \& Geçel, 2006). Çeviri eserlerde anlam karmaşıklığını ortadan kaldırmak için kahraman adları Türkçeleştirilmelidir (Kıbrıs, 2000; Oğuzkan, 1997). Kitapta tekerlemelere ve şarkılara yer verilip bunların resimlerle canlandırılması özellikle okul öncesi dönem çocukları için ilgi çekiciliği arttırır (Demirel vd., 2010). Bazı çocuklar için öykünün ortamı ilgi çekiciyken bazıları için hareketin daha önemli olduğu unutulmamalıdır (Çakmak-Güleç \& Geçel, 2006). Yaş grupları ayrımı yapılırken gerek içinde bulunulan toplumun okuma anlayışına gerekse hitap edilen grubun gelişim özellikleri, ilgi ve gereksinimleri dikkate alınmalıdır (Çiftçi, 2013).

Konu ve Tema. Tema yazarın okuyucuda uyandırmak istediği etki ve paylaşmak istediği duygulardır. Konu ise yazarın üzerinde söz söylediği olay ya da durumdur (Sever vd., 2013). Çocuklar, tema ve konu ilişkisi zayıf/belirsiz olan eserlerinin ne sanat yönünden ne de eğitsel yönününden kolaylıkla yararlanabilir (Oğuzkan, 1997). Kitapta giriş, gelişme ve sonuç bölümleri belirgin bir şekilde tasarlanmalıdır. Araştırma konusunu oluşturan çocuk kitaplarında özel gereksinimli olma durumunun anlatılması, işlenen temaya bağlıdır. Tema, güncel hayat üzerinden seçilen konularla verilmelidir. Çocukların kendi yaşam alanlarıyla ilgili olan kitaplarla erken çocukluk döneminde etkileşim halinde olmaları, ileri zamanlardaki kitap okuma alışkanlığını etkileyen bir unsurdur. Kitaplar, okurun tercihte bulunmasını; bireysel ve toplumsal olarak doğru kabul edilen durumları keşfetmesini sağlamalıdır. Çocuğun dünyasında olmayan unsurlardan uzak durup yetişkin gerçekliğinden arındırılmış zengin yaşantılara yer verilmelidir (Sever, 2002). Kurgular çocuğun kendisini ve sonrasında başkalarını tanımaya yönlendirecek şekilde planlanmalı, ele alınan yetersizlik türü çocuğa tanıtılmalıdır. İçinde yaşanılan toplumun örf, adet ve geleneklerine uymayı sağlama amacıyla korkutucu içeriklere yer verilmemelidir (Sever, 2002).

Karakterler. Okul öncesi dönemdeki çocuklara hitap eden kitaplarda az sayıda kahraman olması faydalıdır (Çakmak-Güleç \& Geçel, 2006). Üç yaş civarında bir çocuk üç kahraman arasında yaşanan bir olayı algılayabilirken bu sayı yaş grubu ilerledikçe kademeli olarak arttırılabilir (Karataş, 2014). Kahramanlar aracılığıly çocuklara sorumluluk sahibi olma, farklılıklara saygı duyma ve demokratik 
yaşama kültürü yansıtılmalıdır (Sever, 2002). Çocuklar, kendilerinden bazı özellikler ve davranış örnekleri taşıyan kahramanlarla daha kolay özdeşim kurar (Yıldız-Demirtaş, 2016). Bu nedenle kahramanların iyi tasarlanması gerekir: Abartıdan uzak, iyi karakterli, duygularını ifade edebilen kahramanlar kurgulanmalıdır (Turla \&Tür, 1999). Özel gereksinimi olan kahramanın da çok boyutlu yansıtılması ve olumlu kişilik özellikleri taşıması gerekir (Dyches \& Prater, 2000). Kahramanlar insan ya da hayvan olabilir. Önemli olan gerçek/gerçekçi ve problem çözücü olmalarıdır (Demirel vd., 2010). Seçilen karakterin yetişkin gibi düşünmesi ve yetişkin duygularına sahip olması inandırıcılı̆̆ını kaybetmesine yol açar (Çakmak-Güleç \& Geçel, 2006).

Resimler. Güzel resimler bir kitabın satılmasını sağlayabilir. Daha önemlisi görsel algılama, öğrenmenin kalıcı olmasını sağlar (Çakmak-Güleç \& Geçel, 2006). Okumaya başlangıç aracı olarak hazırlanan kitaplarda resimler metni açıklayıcı, yorumlayıcı ve tamamlayıcı nitelikte olmalıdır. Bir çocuğa uzun uzun bir zürafayı veya aslanı anlatmak yerine bu hayvanların iyi yapılmış resimlerinden faydalanmak kuşkusuz daha verimli olur (Kıbrıs, 2000; Oğuzkan, 1997). Resimlerdeki gölgeler ve 1şık oyunları çocuğu şaşırtır. Yapılan çizimler gerçekçi olmalı ve ayrıntılara yer verilmelidir (ÇakmakGüleç \& Geçel, 2006). Küçük yaş grubuna hitap eden resimlerde soyut kavramlara yönelmemek gerekir. Örneğin ördek ördeğe, araba arabaya benzemelidir (Şirin, 1994). Kitapta iki sayfanın birleştiği yere "oluk" denir. Oluk üzerinden geçen bir resmin iki yarısının görüntüyü bozmayacak şekilde yerleştirilmesi gerekir (Çakmak-Güleç \& Geçel, 2006).

Okul öncesi dönem çocukları için Türkiye'de yayımlanmış kitaplara yönelik alanyazında yapılan çalışmalara bakılacak olursa belirli yayınevlerine (Bulut \& Kuşdemir, 2013), belirli yazarlara ait çocuk kitaplarının incelendiği araştırmalar (Erdoğan-Horosan, 2015; Doğan, 2015; Kuru, 2016); çocuk kitaplarının iç yapı özelliklerini (Çeçen \& Aydemir, 2011; Pektaş, 2015), dış yapı özelliklerini (Şeref, 2018; Toran\& Dilek, 2017; Ulutepe, 2010) ya da her ikisini birden inceleyen (Demirtaş, 2015; Gönen, Karakuş, Uysal, Kehci, Ulutaş \& Kahve, 2016; Kardaş-Koçak, 2017) araştırmalar olduğu görülmektedir. Ancak özel gereksinimliliği konu edinen ya da içerisinde özel gereksinimli karakteri bulunan Türkçe çocuk kitaplarını inceleyen sınırlı sayıda çalışma bulunmaktadır. Gönen, Dursun, Topçu-Bilir, Tarman ve Nur (2015), ele aldıkları 30 resimli çocuk kitabını konu ve yetersizlik türünün tanımlanması açısından incelemiştir. Çocuk kitaplarında en fazla farklı olma durumu ve görme yetersizliğinin işlendiği, resimlerin gerçekçi olduğu ve kitapların empati yeteneğini geliştirir nitelikte olduğu sonuçlarına varılmıştır. Işıtan (2016), yaptığı nitel çalışmada 1990-2015 yılları arasında okul öncesi dönem çocuklarının karşılaşabileceği zor durumlar (özel gereksinimli olma, boşanma, sünnet olma, tırnak yeme vb.) için özel amaçla yazılmış kitapların betimsel analizini yapmıştır. Çalışma sonucunda incelenen tüm kitaplar arasında özel gereksinimli olma durumunu işleyen kitapların oranının oldukça az olduğu bulunmuştur. Kaymaz (2017), çalışmasında özel 
gereksinimlilik durumunun resimli öykü kitaplarında çocuk kitaplarının temel özellikleri, resimli öykü kitaplarının temel bileşenleri ve biçimsel özellikleri bağlamında nasıl temsil edildiğini ortaya koymayı amaçlamıştır. Karma araştırma yönteminin kullanıldığı bu çalışmaya 1996-2016 yılları arasında 3-8 yaş arası çocuklar için yayımlanmış 61 çocuk kitabı dahil edilmiştir. Yazar, incelediği kitaplar arasına temel yetersizlik durumlarının yanı sıra süreğen hastalık ve yeme bozuklukları gibi konuları içeren kitapları da dahil etmiştir. Çalışmanın bulgularında yetersizliği olan karakterin kitapların çoğunda (\%85) ana karakter olduğunu, problem çözümünde büyük oranda (\%72.1) aktif rol aldıklarını ve büyük oranda (\%95.1) gerçekçi bir şekilde resmedildiklerini belirtilmektedir.

Alan yazındaki çalışmalar incelendiğinde, içeriğinde özel gereksinimli kahramanı olan kitaplar üzerinde, bu durumun aktarılmasına yönelik ölçütleri barındıran bir ölçü aracının kullanıldığı herhangi bir çalışmaya rastlanmamıştır. Bu araştırma, içinde özel gereksinimli kahramanların olduğu çocuk kitaplarının yukarıda derlenen çocuk kitabı ölçütlerine ne derece uyduğunu incelemesi ve kitaplarda geçen özel gereksinimli olma durumunun aktarımını değerlendirmesi bakımından önem taşımaktadır.

$\mathrm{Bu}$ araştırmanın amacı, 0-8 yaş arası çocuklar için basılmış özel gereksinimli olma durumunu anlatan Türkçe ve çeviri çocuk kitaplarının iç ve dış yapı özelliklerinin bir çocuk kitabının taşıması gereken çocuk edebiyatı ölçütlerini ne derece karşıladığını belirlemeye çalışmaktır. Bu amaçla aşağıdaki sorulara yanıt aranmıştır:

1. Özel gereksinimli olma durumunu anlatan çocuk kitapları, dış yapı (biçimsel) ölçütlerini ne derece karşılamaktadır?

2. Özel gereksinimli olma durumunu anlatan çocuk kitapları, iç yapı (içeriksel) ölçütlerini ne derece karşılamaktadır?

\section{YÖNTEM}

\section{Araştırma Deseni}

Araştırmada var olan durumu olduğu şekliyle betimlemeyi amaçlayan betimsel tarama modeli kullanılmıştır. Tarama modelinde ele alınan nesne, birey ya da olay kendi koşulları içinde ve olduğu gibi tanımlanmaya çalışılır (Creswell, 2014).

\section{Araştırma Grubu}

Bu nedenle arama seçeneği olarak internetten anahtar kelimeler ile bulunan çocuk kitapları ve çocuk kitabı yayımcılarının kataloglarında bulunan 5 bini aşkın kitap taranıp bunlar üzerinde amaçlı örnekleme yöntemlerinden ölçüt örneklem yöntemi kullanılmıştır. Ölçüt örnekleme yönteminde 
araştırmacının belirlediği ya da önceden belirlenmiş olan bir dizi ölçütü karşılayan tüm birimler örnekleme dahil edilir (Patton, 2001). Bu bağlamda belirlenen ölçütler; (a) erken çocukluk dönemine hitap etme (0-8 yaş arası), (b) hikaye türünde olma ve (c) içinde özel gereksinimli kahramanı olmasıdır. 8 yaş ve üzeri için uygun olduğu belitilen kitapların da ölçütü karşıladığı kabul edilerek araştırmaya dahil edilmiştir. Tarama sonucu 20 kitap içinde 30 hikaye saptanmıştır. $\mathrm{Bu}$ kitaplardan birinin (Aksak Ali) basımına ulaşılamadığı için, ikisi (Otizm ve Kardeşim, Kimse Size Engel Olamaz) ise hikaye türü kapsamında değerlendirilemeyeceği için araştırmaya dahil edilmemiştir. Sonuç olarak 27 hikaye örneklem olarak araştırmaya dahil edilmiştir. Çalışmada incelenen çocuk kitaplarına yönelik bibliyografya EK1'de yer almaktadır.

\section{Veri Toplama Arac1}

Araştırma kapsamında, birinci yazar tarafından çocuk edebiyatıyla ilgili kaynak kitaplar ve konu hakkında yapılmış makale/ tezlerden faydalanılarak 77 sorudan oluşan veri toplama aracı geliştirilmiştir. Veri toplama aracı ile ilgili özel eğitim alanında doktora düzeyinde uzman bir akademisyenin görüşleri alınarak gerekli düzenlemeler yapılmıştır. Veri toplama aracı 2 bölümden oluşmaktadır: İlk bölüm dış yapı (biçim) özelliklerini değerlendiren 31 sorudan oluşurken ikinci bölüm iç yapı (içerik) özelliklerini değerlendiren 46 sorudan oluşmaktadır. Soruların tamamı olumlu soru köküne sahip olup “yeterli”, "kısmen yeterli” ve “yetersiz” seçenekleri ile değerlendirilmiştir.

\section{Verilerin Toplanmas1}

27 hikayenin tamamı, geliştirilen veri toplama aracı ile değerlendirilmiştir. Tüm soru kökleri olumlu olduğundan "yeterli” için 3, "kısmen yeterli” için 2 ve "yetersiz” için 1 puan verilmiştir. Elde edilen maximum ve minimum puanların aralığ 3 eşit parçaya bölünerek bu sonuca göre yeterli- kısmen yeterli ve yetersiz puan aralıkları belirlenmiştir. Bulguların değerlendirilmesinde esas alınan değer aralıkları Tablo 1'de yer almaktadır. Buna göre elde edilen bulguların frekans $(f)$, yüzde (\%) ve ortalamaları (X) hesaplanmıştır.

Araştırmada uygulama güvenirliği verileri toplanmıştır. Örneklemin \%30’u (f=8), zihin engelliler öğretmenliği lisans mezunu olan 3 öğretmen tarafindan aynı veri toplama aracı ile değerlendirilmiş ve \%95,3 (ranj=88,3-97,4) oranında benzerlik olduğu görülmüştür. Güvenirlik verileri toplanmadan önce öğretmenlere bir çocuk kitabının taşıması gereken ölçütler açıklanmıştır.

Tablo 1. Değer Aralıkları

\begin{tabular}{rcc}
\hline Yeterli & Kismen Yeterli & Yetersiz \\
\hline $3,00-2,43$ & $2,42-2,24$ & $2,23-1,00$ \\
\hline & Erken Çocukluk Çalışmaları Dergisi \\
Cilt 3· Sayı 2 2 Ekim & 2019 & $\begin{array}{l}\text { Journal of Early Childhood Studies } \\
\text { Volume 3 Issue 2 October }\end{array}$
\end{tabular}




\section{BULGULAR}

Çalışma grubu içinde 9 hareket engeli, 7 açıkça gereksinim türü belirtilmeksizin farklı özelliklere sahip olma durumu, 3 işitme yetersizliği, 3 duygu/davranış bozukluğu (obsesif kompulsif bozukluk ve Tourette sendromu), 2 görme yetersizliği, 1 öğrenme güçlüğü (disleksi), 1 down sendromu ve 1 otizm konulu hikaye bulunmaktadır.

Özel gereksinimli kahramanı bulunan çocuk kitapları, geliştirilen veri toplama aracı ile değerlendirilmiş; elde edilen sonuçlar tablolar halinde verilmiştir. Hikayelerin dış yap1 (biçim) özelliklerinin ölçütleri ne derece karşıladığı Tablo 2'de verilmiştir.

Tablo 2. Kitapların Dış Yapı (Biçimsel) Özellikleri

\begin{tabular}{|c|c|c|c|c|c|c|c|}
\hline \multirow{2}{*}{ D1ş Yapı Özellikleri } & \multicolumn{2}{|c|}{ Yeterli } & \multicolumn{2}{|c|}{$\begin{array}{l}\text { K1smen } \\
\text { Yeterli }\end{array}$} & \multicolumn{2}{|c|}{ Yetersiz } & \multirow{2}{*}{$\begin{array}{l}\text { Puan } \\
\mathrm{X}\end{array}$} \\
\hline & $\mathrm{f}$ & $\%$ & $\mathrm{f}$ & $\%$ & $\mathrm{f}$ & $\%$ & \\
\hline 1. Kitabın şekli uygun mu? & 27 & $\% 100,0$ & 0 & $\% 0,0$ & 0 & $\% 0,0$ & 3,00 \\
\hline 2. Kitabin boyutu uygun mu? & 14 & $\% 51,9$ & 10 & $\% 37,0$ & 3 & $\% 11,1$ & 2,41 \\
\hline 3. Kitap kolay taşınabilir mi? & 25 & $\% 92,6$ & 1 & $\% 3,7$ & 1 & $\% 3,7$ & 2,89 \\
\hline 4. Kitabın kapağı bez ya da mukavva mı? & 27 & $\% 100,0$ & 0 & $\% 0,0$ & 0 & $\% 0,0$ & 3,00 \\
\hline 5. Kitabın kağıdı mat mı? & 27 & $\% 100,0$ & 0 & $\% 0,0$ & 0 & $\% 0,0$ & 3,00 \\
\hline 6. Sayfalar temizlenebilir mi? & 13 & $\% 48,1$ & 0 & $\% 0,0$ & 14 & $\% 51,9$ & 1,96 \\
\hline 7. Sayfaların birleşimi iplik dikiş mi? & 21 & $\% 77,8$ & 0 & $\% 0,0$ & 6 & $\% 22,2$ & 2,56 \\
\hline 8. Yazı puntosu yaş seviyesine uygun mu? & 27 & $\% 100,0$ & 0 & $\% 0,0$ & 0 & $\% 0,0$ & 3,00 \\
\hline 9. Sayfaların alt ve üst kısımlarında boşluk var mı? & 27 & $\% 100,0$ & 0 & $\% 0,0$ & 0 & $\% 0,0$ & 3,00 \\
\hline 10. Sayfaların sağ ve sol kısımlanında boşluk var mı? & 26 & $\% 96,3$ & 0 & $\% 0,0$ & 1 & $\% 3,7$ & 2,93 \\
\hline 11. Kapak resmi kitabın konusuna uygun mu? & 15 & $\% 55,6$ & 2 & $\% 7,4$ & 10 & $\% 37,0$ & 2,19 \\
\hline 12. Kapaktaki resim kitabın içinde de bulunuyor mu? & 16 & $\% 59,3$ & 1 & $\% 3,7$ & 10 & $\% 37,0$ & 2,22 \\
\hline 13. Kitabın iç kapağında resim var mı? & 3 & $\% 11,1$ & 0 & $\% 0,0$ & 24 & $\% 88,9$ & 1,22 \\
\hline 14. Ön kapakta kitabın adı yazıyor mu? & 27 & $\% 100,0$ & 0 & $\% 0,0$ & 0 & $\% 0,0$ & 3,00 \\
\hline $\begin{array}{r}\text { Erken Çocukluk Çalışmaları Dergisi } \\
\text { Cilt } 3 \cdot \text { Sayı } 2 \cdot \text { Ekim }\end{array}$ & & $\begin{array}{l}\text { rnal of Early } \\
\text { ume } 3 \cdot \text { Issu }\end{array}$ & $\begin{array}{l}\text { ldhoo } \\
\text { Octol }\end{array}$ & $\begin{array}{l}\text { d Studies } \\
\text { er }\end{array}$ & & & \\
\hline
\end{tabular}




\begin{tabular}{|c|c|c|c|c|c|c|c|}
\hline 15. Ön kapakta kitabın konusu yazıyor mu? & 5 & $\% 18,5$ & 0 & $\% 0,0$ & 22 & $\% 81,5$ & 1,37 \\
\hline 16. Ön kapakta yazarın adı yazıyor mu? & 22 & $\% 81,5$ & 0 & $\% 0,0$ & 5 & $\% 18,5$ & 2,63 \\
\hline 17. Ön kapakta yayınevinin adı yazıyor mu? & 26 & $\% 96,3$ & 0 & $\% 0,0$ & 1 & $\% 3,7$ & 2,93 \\
\hline $\begin{array}{l}\text { 18. Ön kapakta kitabın uygun olduğu yaş grubu } \\
\text { belirtiliyor mu? }\end{array}$ & 8 & $\% 29,6$ & 0 & $\% 0,0$ & 19 & $\% 70,4$ & 1,59 \\
\hline $\begin{array}{l}\text { 19. Ön kapakta yazılmamış bilgiler iç kapakta yer alıyor } \\
\text { mu? }\end{array}$ & 3 & $\% 11,1$ & 0 & $\% 0,0$ & 24 & $\% 88,9$ & 1,22 \\
\hline 20. Resimleyenin adı belirtilmiş mi? & 27 & $\% 100,0$ & 0 & $\% 0,0$ & 0 & $\% 0,0$ & 3,00 \\
\hline 21. Çevirenin adı belirtilmiş mi? & 27 & $\% 100,0$ & 0 & $\% 0,0$ & 0 & $\% 0,0$ & 3,00 \\
\hline 22. Kitabın kaçıncı baskı olduğu yazıyor mu? & 14 & $\% 51,9$ & 0 & $\% 0,0$ & 13 & $\% 48,1$ & 2,04 \\
\hline 23. Arka kapakta kitabın tanıtımı yapilıyor mu? & 23 & $\% 85,2$ & 0 & $\% 0,0$ & 4 & $\% 14,8$ & 2,70 \\
\hline 24. Arka kapakta kitabın fiyatı belirtiliyor mu? & 12 & $\% 44,4$ & 0 & $\% 0,0$ & 15 & $\% 55,6$ & 1,89 \\
\hline 25. Kitabın üzerinde sayfa numaraları yazılıyor mu? & 16 & $\% 59,3$ & 7 & $\% 25,9$ & 4 & $\% 14,8$ & 2,44 \\
\hline 26. Kitabın sözlüğü var mı? & 0 & $\% 0,0$ & 0 & $\% 0,0$ & 27 & $\% 100,0$ & 1,00 \\
\hline 27. Yazar/yazarlar hakkında bilgilendirme yapılıyor mu? & 16 & $\% 59,3$ & 1 & $\% 3,7$ & 10 & $\% 37,0$ & 2,22 \\
\hline 28. Yazarın diğer yapıtlanı listeleniyor mu? & 13 & $\% 48,1$ & 0 & $\% 0,0$ & 14 & $\% 51,9$ & 1,96 \\
\hline 29. Yayınevinin diğer yapıtları listeleniyor mu? & 8 & $\% 29,6$ & 0 & $\% 0,0$ & 19 & $\% 70,4$ & 1,59 \\
\hline 30. Metin dil uzmanının incelemesinden geçiyor mu? & 4 & $\% 14,8$ & 0 & $\% 0,0$ & 23 & $\% 85,2$ & 1,30 \\
\hline $\begin{array}{l}\text { 31. Metin alan (eğitim) uzmanının incelemesinden } \\
\text { geçiyor mu? }\end{array}$ & 3 & $\% 11,1$ & 0 & $\% 0,0$ & 24 & $\% 88,9$ & 1,22 \\
\hline
\end{tabular}

Tablo 2'de verilen bulgular incelendiğinde diş yapı özelliklerinden 15 madde yeterli, 1 madde kısmen yeterli, 15 madde yetersiz düzeyde bulunmuştur.

Hikayelerin iç yapı (içeriksel) özelliklerinin kriterleri ne ölçüde karşıladığının sonuçları Tablo 3’te verilmiştir. Tablo 3'te de görüldügü gibi iç yapı özelliklerinden 25 madde yeterli, 2 madde kısmen yeterli ve 19 madde yetersiz düzeyde bulunmuştur. 
Tablo 2. Kitapların İç Yapı (İçeriksel) Özellikleri

İç Yapı Özellikleri

Yeterli $\begin{aligned} & \text { Kismen } \\ & \text { Yeterli }\end{aligned} \quad$ Yetersiz Puan

\begin{tabular}{|c|c|c|c|c|c|c|c|}
\hline & $f$ & $\%$ & $f$ & $\%$ & $f$ & $\%$ & $\mathrm{X}$ \\
\hline 1. Anlatılan olayın çocuk dünyasında yeri var mı? & 19 & $\% 70,4$ & 8 & $\% 29,6$ & 0 & $\% 0,0$ & 2,70 \\
\hline 2. Kitabın adı Türkçe mi? & 27 & $\% 100,0$ & 0 & $\% 0,0$ & 0 & $\% 0,0$ & 3,00 \\
\hline 3. Kahramanların adı Türkçe mi? & 21 & $\% 77,8$ & 1 & $\% 3,7$ & 5 & $18,5 \%$ & 2,59 \\
\hline 4. Kitabın adı ilgi çekici mi? & 23 & $\% 85,2$ & 4 & $\% 14,8$ & 0 & $\% 0,0$ & 2,85 \\
\hline 5. Kitabın adı özel gereksinime yönelik merak uyandırıyor mu? & 21 & $\% 77,8$ & 2 & $\% 7,4$ & 4 & $14,8 \%$ & 2,63 \\
\hline 6. Metinde zaman bildiriliyor mu? & 8 & $\% 29,6$ & 2 & $\% 7,4$ & 17 & $63,0 \%$ & 1,67 \\
\hline 7. Metinde mekan bildiriliyor mu? & 17 & $\% 63,0$ & 4 & $\% 14,8$ & 6 & $22,2 \%$ & 2,41 \\
\hline 8. Kitabın konusu çocuğun yaşına uygun mu? & 21 & $\% 77,8$ & 6 & $\% 22,2$ & 0 & $\% 0,0$ & 2,78 \\
\hline 9. Kahraman sayısı yaş grubunun seviyesine uygun mu? & 25 & $\% 92,6$ & 2 & $\% 7,4$ & 0 & $\% 0,0$ & 2,93 \\
\hline 10. Kişiler gerçeğe uygun mu? & 23 & $\% 85,2$ & 4 & $\% 14,8$ & 0 & $\% 0,0$ & 2,85 \\
\hline 11. Tema ile konu birbirini destekliyor mu? & 12 & $\% 44,4$ & 9 & $\% 33,3$ & 6 & $\% 22,2$ & 2,22 \\
\hline 12. Özel gereksinimli olma durumun açıklanıyor mu? & 10 & $\% 37,0$ & 4 & $\% 14,8$ & 13 & $\% 48,1$ & 1,89 \\
\hline 13. Özel gereksinime yönelik terminoloji doğru kullanılmış mı? & 9 & $\% 33,3$ & 5 & $\% 18,5$ & 13 & $\% 48,1$ & 1,85 \\
\hline $\begin{array}{l}\text { 14. Ele alınan özel gereksinim türü yalın bir şekilde tanitllyor } \\
\text { mu? }\end{array}$ & 7 & $\% 25,9$ & 5 & $18,5 \%$ & 15 & $\% 55,6$ & 1,70 \\
\hline
\end{tabular}

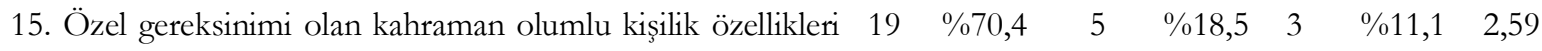
taşıor mu?

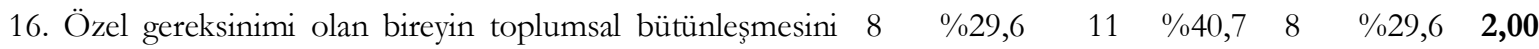
arttırıcı çıkarımlar var mı?

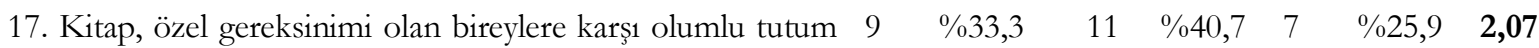
geliştirilmesini sağllyor mu?

18. Kadercilik, alın yazısı gibi unsurlardan arındırılmış mı? $\quad \begin{array}{llllllll}26 & \% 96,3 & 0 & \% 0,0 & 1 & \% 3,7 & 2,93\end{array}$ 


\begin{tabular}{|c|c|c|c|c|c|c|c|}
\hline 19. Kitabın akışı iyi planlanmış mı? & 8 & $\% 29,6$ & 16 & $\% 59,3$ & 3 & $\% 11,1$ & 2,19 \\
\hline 20. Kitapta güncel dil kullanılmış mı? & 27 & $\% 100,0$ & 0 & $\% 0,0$ & 0 & $\% 0,0$ & 3,00 \\
\hline 21. Cümleler anlaşılır mi? & 16 & $\% 59,3$ & 11 & $\% 40,7$ & 0 & $\% 0,0$ & 2,59 \\
\hline 22. Kitap, çocuğun sözcük dağarcığını geliştirir nitelikte mi? & 20 & $\% 74,1$ & 7 & $\% 25,9$ & 0 & $\% 0,0$ & 2,74 \\
\hline $\begin{array}{l}\text { 23. Bilinmeyen sözcüklerin anlamları aynı sayfada açılanıyor } \\
\text { mu? }\end{array}$ & 0 & $\% 0,0$ & 0 & $\% 0,0$ & 27 & $\begin{array}{l}\% 100 \\
0\end{array}$ & 1,00 \\
\hline 24. Çocukların aşina olduğu sözcükler kullanılmış mı? & 17 & $\% 63,0$ & 10 & $\% 37,0$ & 0 & $\% 0,0$ & 2,63 \\
\hline 25. Cümleler tek bir özne ve yüklemden oluşuyor mu? & 6 & $\% 22,2$ & 12 & $\% 44,4$ & 9 & $\% 33,3$ & 1,89 \\
\hline 26. Ses tekrarlar1/tekerlemeler var mi? & 2 & $\% 7,4$ & 6 & $\% 22,2$ & 19 & $\% 70,4$ & 1,37 \\
\hline 27. Fiiller etken çatılı mi? & 26 & $\% 96,3$ & 1 & $\% 3,7$ & 0 & $\% 0,0$ & 2,96 \\
\hline 28. Paragraf uzunluklanı yaş gurubuna uygun mu? & 13 & $\% 48,1$ & 1 & $\% 3,7$ & 13 & $\% 48,1$ & 2,00 \\
\hline 29. Sayfa sayısı hitap ettiği yaş grubuna uygun mu? & 17 & $\% 63,0$ & 7 & $\% 25,9$ & 3 & $\% 11,1$ & 2,52 \\
\hline 30. Kitap, imla ve noktalama kuralları bakımından eksiksiz mi? & 22 & $\% 81,5$ & 3 & $\% 11,1$ & 2 & $\% 7,4$ & 2,74 \\
\hline 31. Parça yöresel/kültürel sözcüklerden arındırılmış mı? & 23 & $\% 85,2$ & 3 & $\% 11,1$ & 1 & $\% 3,7$ & 2,81 \\
\hline 32. Parça ikilemelerden anındırılmış mı? & 18 & $\% 66,7$ & 3 & $\% 11,1$ & 6 & $\% 22,2$ & 2,44 \\
\hline 33. Parça devrik cümlelerden arındırılmış mı? & 6 & $\% 22,2$ & 3 & $\% 11,1$ & 18 & $66,7 \%$ & 1,56 \\
\hline 34. Parça argo söyleyişlerden arındırılmış mı? & 25 & $\% 92,6$ & 2 & $\% 7,4$ & 0 & $\% 0,0$ & 2,93 \\
\hline
\end{tabular}

35. Planı ve bitişi bakımından çocukta başka bir kitap okuma $10 \quad \% 37,0 \quad 13 \quad \% 48,1 \quad 4 \quad \%$ \% $14,8 \quad 2,22$ isteği uyandırıyor mu?

\begin{tabular}{|c|c|c|c|c|c|c|c|}
\hline 36. Resimler renkli mi? & 26 & $\% 96,3$ & 0 & $\% 0,0$ & 1 & $\% 3,7$ & 2,93 \\
\hline 37. Resimler ön planda mi? & 15 & $\% 55,6$ & 2 & $\% 7,4$ & 10 & $\% 37,0$ & 2,19 \\
\hline 38. Sayfaların resim-yazı oranı uygun mu? & 13 & $\% 48,1$ & 0 & $\% 0,0$ & 14 & $\% 51,9$ & 1,96 \\
\hline 39. Resimle metin uyumlu konumlandırılmış mı? & 24 & $\% 88,9$ & 1 & $\% 3,7$ & 2 & $\% 7,4$ & 2,81 \\
\hline 40. Resimler oluğa uygun yerleştirilmiş mi? & 25 & $\% 92,6$ & 1 & $\% 3,7$ & 1 & $\% 3,7$ & 2,89 \\
\hline
\end{tabular}




\begin{tabular}{|c|c|c|c|c|c|c|c|}
\hline 41. Resimler metni tamamlayıcı nitelikte mi? & 11 & $\% 40,7$ & 6 & $\% 22,2$ & 10 & $\% 37,0$ & 2,04 \\
\hline 42. Resimler metni açıklayıcı ve yorumlayıcı nitelikte mi? & 9 & $\% 33,3$ & 8 & $\% 29,6$ & 10 & $\% 37,0$ & 1,96 \\
\hline 43. Kitapta kullanılan resimler ilgi çekici mi? & 14 & $\% 51,9$ & 11 & $\% 40,7$ & 2 & $\% 7,4$ & 2,44 \\
\hline 44. Özel gereksinimi olan bireyi betimleyen resimler var mi? & 15 & $\% 55,6$ & 5 & $\% 18,5$ & 7 & $\% 25,9$ & 2,30 \\
\hline 45. Resimlerde ayrıntılara dikkat edilmiş mi? & 10 & $\% 37,0$ & 9 & $\% 33,3$ & 8 & $\% 29,6$ & 2,07 \\
\hline 46. Resimler hikaye boyunca tutarlılık gösteriyor mu? & 25 & $\% 92,6$ & 2 & $\% 7,4$ & 0 & $\% 0,0$ & 2,93 \\
\hline
\end{tabular}

İç yap1 özellikleri içinde yer alan özel gereksinimli olma durumu ile ilgili maddelere $(12,13,14,15,16,17,44)$ bakıldığında “özel gereksinimi olan karakterin olumlu kişilik özelliği taşıması" ve "özel gereksinimi olan bireyi betimleyen resimlerin bulunması" dışında kalan maddelerin yetersiz puan aldığ1 görülmektedir.

Yapılan inceleme ek olarak ele alınan her çocuk kitabının yeterlilik ortalamaları hesaplanmıştır. Dış yapı başlığı altında genel olarak 3 yapıt yeterli, 9 yapıt kısmen yeterli, 15 yapıt yetersiz; iç yapı başlığı altında altında 13 yapıt yeterli, 5 yapıt kısmen yeterli, 9 yapıt yetersiz bulunmuştur. Hikayelerin genel ortalamalarına bakıldığında ise 11 yapıt yeterli, 5 yapıt kısmen yeterli, 11 yapıt ise yetersiz düzeyde bulunmuştur.

\section{SONUÇ ve TARTIŞMA}

Bu çalışmada, özel gereksinimli olma durumunu anlatan 6-8 yaş arası Türkçe ve çeviri çocuk kitaplarının iç ve dış yapı özelliklerinin bir çocuk kitabının taşıması gereken çocuk edebiyatı ölçütlerini ne derece karşıladığı belirlenmeye çalışılmıştır.

Kitaplarda ele alınan yetersizlik türlerine bakıldığında, çoğunlukla $(n=9)$ hareket engelinin işlendiği görülmektedir. Bu bulgu alanyazın ile paralellik göstermektedir (Leininger, Dyches, Prater \& Heath, 2010). Ancak kitapların hiçbirinde çoklu yetersizlik, hiperaktivite, travmatik beyin hasarı gibi çeşitli yetersizlik türleri olan karakterlere rastlanmamıştır. Yanı sıra kitapların büyük çoğunluğunun yetersizlik türünü tanıtmak amacıyla açık ve tam ifadelere yer vermediği dikkat çekmektedir. Örneğin, incelenen kitaplardan birinde görme yetersizliğini açılamak için yalnızca "Karmiş’in rüyasında her şey simsiyahmış.” ifadesi yer almaktadır. Yetersizlik durumunu çocuğun seviyesine uygun, gerçekçi ve doğru bir şekilde anlatmak oldukça önemlidir. Kitaplardaki özel gereksinimi olan karakterler insan ya da hayvan olarak yer almaktadır. Bu karakterlerin hem yazılı ifadelerde hem de resimlerde yapıcı, arkadaş canlısı ve iyimser olduğu görülmektedir. Özel gereksinimi olan 
karakterlerin güçlüklerle başa çıkabilen ve yetenekleri olan bireyler olması alanyazındaki bulgularla paralellik göstermektedir (Gönen vd., 2015). Geliştirilen veri toplama aracına göre kitaplar, toplam 77 maddeden 40 tanesi için yeterli, 3 tanesi için kısmen yeterli ve 34 tanesi için de yetersiz görülmüştür. Sonuçlar incelendiğinde kitapların gerek dış yapısal, gerekse iç yapısal özellikleri açısından bazı eksikliklerinin olduğu fark edilmiştir.

Dış yapı ile ilgili yetersiz puan alan maddeler; sayfaların temizlenebilir olması (1,67); kapak resminin kitabın konusuyla uygun olması (2,19); kapaktaki resmin kitabın içinde de geçiyor olması $(2,22)$; kitabın iç kapağında resim bulunması (1,22); ön kapakta kitabın konusunun yazması $(1,37)$; ön kapakta hitap ettiği yaş grubunun yazması $(1,59)$; ön kapakta eksik olan bilgilerin iç kapakta verilmesi $(1,22)$; kitabın baskı sayısının bildirilmesi $(2,04)$; arka kapakta kitabın fiyatının belirtilmesi $(1,89)$; kitapta sözlük bulunması $(1,00)$; yazar/yazarlar hakkında bilgilendirme yapılması $(2,22)$; yazarın diğer yapıtlarının listelenmesi (1,96); yayınevinin diğer yapıtlarının listelenmesi $(1,59)$; metnin dil uzmanı tarafindan incelenmesi $(1,30)$ ve metnin alan uzmanı tarafindan incelenmesi $(1,22)$ dir.

İç yapı ile ilgili yetersiz puan alan maddeler ise metinde zaman bildirilmesi (1,67); tema ile konunun birbirini desteklemesi (2,22); Özel gereksinimli olma durumunun aç1klanması (1,89); özel gereksinime yönelik terminolojinin doğru kullanılması (1,85); ele alınan özel gereksinim türünün yalın bir şekilde tanıtılması $(1,70)$; özel gereksinimi olan bireyin toplumsal bütünleşmesini arttırıcı çıkarımlar yapılması (2,00); Özel gereksinimi olan bireylere karşı olumlu tutum geliştirilmesinin sağlanması (2,07); kitabın akışının iyi planlanması (2,19); bilinmeyen sözcüklerin anlamlarının aynı sayfada açıklanması (1,00); cümlelerin tek bir özne ve yüklemden oluşması $(1,89)$; ses tekrarlarına yer verilmesi (1,37); paragrafların yaş grubuna uygun uzunlukta olması $(2,00)$; parçanın devrik cümlelerden arındırılması (1,56); kitabın çocukta başka bir kitap okuma isteği uyandırıyor olması $(2,22)$; resimlerin ön planda olması $(2,19)$; sayfalardaki resim-yazı oranının uygun olması $(1,96)$; resimlerin metni tamamlayıcı nitelikte olması $(2,04)$; resimlerin metni açıklayıcı ve yorumlayıcı nitelikte olması $(1,96)$ ve resimlerde ayrıntıya dikkat edilmesi $(2,07)$ dir.

Elde edilen maddelerden yola çıkılarak yazarlar, yayınevleri ve araştırmacılara şu önerilerde bulunulabilir: Araştırma sürecinde, çocuklar için yayınlanan kitaplar arasında özel gereksinimli olma durumunu işleyen kitapların oldukça sınırlı bir oranı olduğu fark edilmiştir. Farklı ülkelerde yapılan çalışmalarda incelenen çocuk kitaplarının çok daha fazla olduğu (Blaska, 2004), bu nedenle çalışmaların tek bir yetersizlik türünü ele alan çalışmalar üzerinde yoğunlaşabildiği görülmektedir (Golos \& Moses, 2011). Özel gereksinimli olma, toplumda azınlıkta olma gibi hassas ve duyarlı olunması gereken konuları ele alan kitapların basımı için yazarlara çeşitli imkan ve teşvikler sunulabilir. 
Geliştirilen veri toplama aracında özel gereksinimle ilgili olan soruların pek çoğunun yetersiz düzeyde olduğu görülmektedir. Özel gereksinimli olma durumunu işleyen kitapların nitelikli sayılması için hem edebi olarak başarılı olması hem de özel gereksinimi tanıtma, ilgili karakteri nitelikli bir şekilde tasarlama konularında başarılı olması gerekir. Bu sonuçtan yola çıkarak ‘özel gereksinimli olmak' gibi hassas ve alan bilgisi gerektirecek konularda kitabın bir eğitim (alan) uzmanı tarafından incelenmesi ve düzenlenmesi faydalı olabilir.

Çocuk kitaplarına yönelik yazar, yayınevi ve ilgili uzmanların görüş birliğiyle ortak kriterler oluşturulabilir. Bu kriterler kalite standartları haline getirilip çocuk edebiyatının daha nitelikli çıtılar vermesi amaciyla belirleyici konuma getirilebilir.

Kitapların daha erken yaşlara hitap etmesini sağlayacak unsurlar geliştirilebilir. Erken çocukluk dönemi için sayfalarda gizli kısımlar, hareket ettirilebilen bölümler ya da 2 boyutlu parçalar tasarlanıp özel gereksinim daha fonksiyonel ve eğlenceli bir şekilde ele alınabilir. Son olarak yerli yayınlara ağırlık verilmesinin de ilgili kitapların niteliğini arttırabileceği düşünülmektedir.

Araştırmanın bazı sınırlıkları bulunmaktadır. İncelenen kitaplar içerisinde bir kitapta özel gereksinime yönelik 10 ayrı hikaye bulunması nedeniyle bu hikayelerin dış yapı (biçimsel) özellikleri aynı puanları almıştır. Bu alanda eser sayısının az olması sebebiyle ilgili kitap, araştırma sonucunu etkileyen büyük bir faktör olmuştur. Araştırmanın bir başka sınırlılığı ise geliştirilen ölçü aracının yalnızca özel eğitim alanında uzman bir akademisyen tarafindan incelenmiş olması,

çocuk edebiyatı alanında uzmanların görüşünün alınmamış olmasıdır. İleri araştırmalarda konuyu derinlemesine incelemek amacıyla çocuk kitapları üzerine nitel araştırmalar desenlenebilir; özel gereksinimli karakteri bulunan ya da özel gereksinimli olma durumunu konu edinen Türkçe çocuk kitaplarında konuların nasıl işlendiğini daha ayrıntılı incelemek amacıyla içerik analizi yapılabilir. $\mathrm{Bu}$ alanda yazılmış kitaplara yönelik satış oranları ile okul öncesi ve ilkokul öğretmenlerinin sınıflarında bu tür kitaplara ne kadar yer verdiği gibi konular araştırılabilir.

\section{KAYNAKÇA}

Blaska, J. (2004). Children's literature that includes characters with disabilities or illnesses. Disability Studies Quarterly, 24(1).

Bulut, P. \& Kuşdemir, Y. (2013). Tübitak tarafindan yayınlanan çocuk kitaplarının içerik özelliklerinin incelenmesi. International Periodical For The Languages, Literature and History of Turkish or Turkic, 8(12), 215-226.

Creswell, J. W. (2014). Research design: Qualitative, quantitative, and mixed methods approaches (4th edition). Sage Publication. 
Çakmak-Güleç, H. \& Geçgel, H. (2006). Cocuk edebiyatı: Okul öncesinde edebiyat ve kitap. Ankara: Pegem Akademi.

Çeçen, M.A. \& Aydemir, F. (2011). Okul öncesi hikâye kitaplarının okunabilirlik açısından incelenmesi. Mustafa Kemal Üniversitesi Sosyal Bilimler Enstitüsü Dergisi, 8(16),185-194.

Çiftçi, F. (2013). Çocuk edebiyatında yaş gruplarına göre kitaplar ve özellikleri. Muş Alparslan Üniversitesi Sosyal Bilimler Dergisi, 1(1), 125- 137.

Çuhaloğlu-İmrak, H. \& Sı̆̆ıtmaç, A. (2011). Kaynaştırma uygulanan okul öncesi sınıflarda akran ilişkilerinin incelenmesi. International Journal of Early Childhood, 3(1), 38- 65.

Demircan, C. (2006). Tübitak çocuk kitaplı̆̆ dizisindeki kitapların dış yapısal ve iç yapısal olarak incelenmesi. Mersin Üniversitesi Ë̈itim Fakültesi Dergisi, 2(1), 12- 27.

Demirel, Ş., Çeçen, M.A., Seven, S., Tozlu, N. \& Uludağ, M.E. (2010). Edebi metinlerle çocuk edebiyatı. Ankara: Pegem Akademi.

Demirtaş, A. (2015). Türk çocuk yazını eserlerinin iç ve dış yapısal özellikleri. (Yayımlanmamış Yüksek Lisans Tezi). Mersin Üniversitesi, Mersin.

Doğan, Ç. (2015). Sevim Ak'ın çocuk kitaplarının çocuk edebiyatının temel ögeleri yönünden incelenmesi ve Türkçe eğitimine katkısı. (Yayımlanmamış Yüksek Lisans Tezi). Erciyes Üniversitesi, Kayseri.

Dyches, T.T. \& Prater,M.A. (2000). Developmental disability in children's literature: Issues and annotated bibliography. Arlington, VA: Developmental Disabilities of the Council for Exceptional Children.

Eratay, E. \& Sazak-Pınar, E. (2006). Genel eğitim sınıflarındaki zihinsel engelli öğrencilerin arkadaşlık ilişkilerinin incelenmesi. Abant İzæet Baysal Üniversitesi Sosyal Bilimler Enstitüsü Dergisi, 13(2), 24- 47.

Erdoğan-Horosan, A. (2015). Zeynep Cemali'nin çocuk kitaplarının çocuk edebiyatının temel ögeleri açısından incelenmesi. (Yayımlanmamış Doktora Tezi). Necmettin Erbakan Üniversitesi, Konya.

Gönen, M., Dursun, A., Topçu-Bilir, Z., Tarman, I. \& Nur, I. (2005). A study on the depiction of disability in illustrated story boks. Revista de Cercetare si Interventie Sociala, 50, 275-292.

Gönen, M., Karakuş, H., Uysal, H., Kehci, A., Ulutaş, Z. \& Kahve, Ö. (2016). Resimli çocuk kitaplarının içerik ve resimleme özelliklerinin bazı değişkenler açısından incelenmesi. Hacettepe Üniversitesi Eğitim Fakültesi Dergisi, 31(4), 724-735.

Golos, D. B., \& Moses, A. M. (2011). Representations of deaf characters in children's picture books. American Annals of the Deaf, 156(3), 270-282.

Grenby, M.O. (2008). Children's literature. Edinburgh: Edinburgh University Press.

Gürdal-Ünal, A. (2011). Türk çocuk edebiyatında engellilik 1969-2009. İstanbul: Evrensel Basım Yayın. 
Işıtan, S. (2016). Özel amaçla yazılmış çocuk kitapları. International Periodical fort he Languages, Literature and History of Turkish of Turkic, 11(4), 471-492.

Karadağ, F., Yıldız-Demirtaş, V. \& Girli, A. (2014). Okul öncesi dönemde akranların sınıflarındaki özel gereksinimli öğrenciyi tercih etme durumları. Mehmet Akif Ersoy Üniversitesi Eğitim Fakeïltesi Dergisi, 31, 191- 215.

Karasar, N. (1998). Bilimsel araștırma yöntemi. (8. baskı). Ankara: Nobel Yayın.

Karataş. E. (2014). Çocuk edebiyatında "karakter" kavram1. Muğla Sıtke Kocaman Üniversitesi Sosyal Bilimler Enstitüsü Dergisi, 33, 60- 79.

Karatay, H. (2011). Karakter Eğitiminde Edebi Eserlerin Kullanımı. International Periodical For the Languages, Terature and History of Turkish or Turkic, 6(1), 1439- 1454.

Kardaş-Koçak, M. (2017). 2000-2014 yılları arasında okul öncesi dönem çocukları için yayınlanmış olan hikâye kitaplarının diş yap1, iç yap1 ve resimleme nitelikleri açısından incelenmesi. (Yayımlanmamış Yüksek Lisans Tezi). Trakya Üniversitesi, Edirne.

Kaymaz, Ç. (2017). Özel gereksinimliliği içeren Türkçe ve çeviri resimli çocuk kitaplarının incelenmesi. (Yayımlanmamış Yüksek Lisans Tezi). Hacettepe Üniversitesi, Ankara.

Kıbrıs, İ. (2000). Yeni yüzynl için çocuk edebiyatı. Ankara: Eylül Kitap ve Yayınevi.

Kuru, S. (2016). Ayşe Yamaç'ın çocuk romanlarının değerler eğitimi ve dil zenginliği açısından incelenmesi. (Yayımlanmamış yüksek lisans tezi). Uşak Üniversitesi, Uşak.

Külük, C.Ş. (2013). Resimli çocuk kitaplarının nitelik sorunsalı ve çocuğun sanat eğitimi sürecindeki yeri: "Delioğlu'nun resimlediği yapttlar üzerine bir inceleme". Ankara Üniversitesi Eğitim Fakültesi Dergisi, 2(2), 393-417.

Lausley, K.M. \& Heflin, L.J. (2000). Enhancing social skills of kindergarten children with autism through the training of multiple peers as tutors. Journal of Autism and Developmental Disorders, 30(3), 183-193.

Leininger, M., Dyches, T. T., Prater, M. A., \& Heath, M. A. (2010). Newbery award winning books 1975-2009: How do they portray disabilities?. Education and Training in Autism and Developmental Disabilities, 45(4), 583-596.

Lynch-Brown, C. \& Tomlinson, C.M. (1998). Essentials of children's literature. (3.bask1). Needham Heights, MA: Allyn and Bacon.

Locke, J., Ishijima, E. H., Kasari, C. \& London, N. (2010). Loneliness, friendship quality and the social networks of adolescents with high-functioning autism in an inclusive school setting. Journal of Research in Special Educational Needs, 10, 74-81.

Oğuzkan, A.F. (1997). Yerli ve yabancı yaz̧arlardan örneklerle çocuk edebiyatı. Ankara: Emel Yayıncilık.

Patton, M.Q. (2001). Qualitative research \& Evaluation methods. (3.bask1). London: Sage Publications. 
Pektaş, D. (2015). Okul öncesi dönem resimli çocuk kitaplarındaki dil sanatlarının incelenmesi. (Yayımlanmamış Yüksek Lisans Tezi). Hacettepe Üniversitesi, Ankara.

Sever, S., Adıüzzel, Ö., Dilidüzgün, S. \& Öztürk, A. (2013). Okul öncesinde gocuk edebiyatı. Eskişehir: Anadolu Üniversitesi Yayını.

Sever, S. (2002). Çocuk kitaplarında yansitılan şiddet. Ankara Üniversitesi Eg̈itim Bilimleri Fakültesi Dergisi, 32(1-2), 25- 37.

Şeref, G. (2018). Okul öncesi dönem çocuklarına yönelik masal kitaplarındaki illüstrasyonların incelenmesi. (Yayımlanmamış Yüksek Lisans Tezi). Anadolu Üniversitesi, Eskişehir.

Şirin, M.R. (1994). 99 soruda çocuk edebiyatı. İstanbul: Çocuk Vakfi Yayınları.

Toran, M. \& Dilek, A. (2017). Cocuklar ve kitaplar: Piaget'nin oyun kuramina göre bir değerlendirme. Yaşadıkȩa Eğitim, 31(1), 41-54.

Turla, A. \& Tür, G. (1999). Okul öncesinde çocuk, edebiyat ve kitap. (1.baskı). İstanbul: Ya-Pa Yayınc1l1k.

Ulutepe, Z. (2010). Okul öncesi dönem hikaye kitabı resimlemelerinin tasarım ilkelerine uygunluğunun incelenmesi. (Yayımlanmamış Yüksek Lisans Tezi). Gazi Üniversitesi, Ankara.

Yıldız-Demirtaş, V. (2016). Popüler çeviri çocuk romanlarının içerik bakımından incelenmesi. Selcuk Üniversitesi Edebiyat Fakültesi Dergisi, 36, 435-466. 
EK1. İncelenen Çocuk Kitapları Bibliyografyası

\begin{tabular}{|c|c|c|c|c|c|c|c|c|}
\hline No & Kitabın Adı & Yayınevi & Kitabın Yazarı & Çeviren & Resimleyen & $\begin{array}{c}\text { Türkiye'de İlk } \\
\text { Basımı }\end{array}$ & İncelenen Baskısı & $\begin{array}{l}\text { Sayfa } \\
\text { Say1s1 }\end{array}$ \\
\hline $\mathrm{K} 1$ & Bana Özürlü Deme & $\begin{array}{l}\text { Erdem } \\
\text { Yayınlar1 }\end{array}$ & Thomas Pat & $\begin{array}{c}\text { Özlem } \\
\text { Mumcuoğlu }\end{array}$ & Lesley Harker & Eylül 2011 & 1.(Son Basim) & 22 \\
\hline K2 & Barış’n Gezintisi & $\begin{array}{l}\text { TÜBİTAK } \\
\text { Yayınlar1 }\end{array}$ & Laurie Lears & $\begin{array}{l}\text { Mine Özyurt- } \\
\text { Killç }\end{array}$ & Karen Ritz & Eylül 2015 & 1.(Son Basım) & 34 \\
\hline $\mathrm{K} 3$ & Bay Endişe & $\begin{array}{l}\text { TÜBİTAK } \\
\text { Yayınları }\end{array}$ & Holly L. Niner & $\begin{array}{l}\text { Mine Özyurt- } \\
\text { Kıliç }\end{array}$ & Greg Swearing & Eylül 2015 & 1.(Son Basım) & 34 \\
\hline K4 & $\begin{array}{l}\text { Cemile Arkadaşına } \\
\text { Yardım Ediyor }\end{array}$ & $\begin{array}{l}\text { Kaknüs } \\
\text { Yayıncillk }\end{array}$ & $\begin{array}{l}\text { Aline de } \\
\text { Petingy }\end{array}$ & $\begin{array}{l}\text { Seda Darcan- } \\
\text { Çiftçi }\end{array}$ & Nancy Delvaux & - & - & 16 \\
\hline K5 & Bende Disleksi Var & $\begin{array}{l}\text { TÜBİTAK } \\
\text { Yayınları }\end{array}$ & $\begin{array}{l}\text { Jeniffer Moore- } \\
\text { Mallinos }\end{array}$ & Ebru Kılıç & Marta Fabrega & Aralık 2008 & $\begin{array}{l}\text { 2.(Son Basim) } \\
\text { Ekim } 2011\end{array}$ & 31 \\
\hline K6 & Duymamak Böyle Bir Şey & $\begin{array}{l}\text { TÜBİTAK } \\
\text { Yayınları }\end{array}$ & $\begin{array}{l}\text { Jeniffer Moore- } \\
\text { Mallinos }\end{array}$ & Özden Hanoğlu & Marta Fabrega & Ekim 2011 & 1.(Son Basim) & 33 \\
\hline K7 & Elimde Değil & $\begin{array}{l}\text { TÜBİTAK } \\
\text { Yayınları }\end{array}$ & Holly L. Niner & $\begin{array}{l}\text { Mine Özyurt- } \\
\text { Kıllç }\end{array}$ & Merly Treatner & Eylül 2015 & 1.(Son Basim) & 34 \\
\hline K8 & $\begin{array}{l}\text { Engelsiz Masallar } \\
\qquad(10 \text { Masal })\end{array}$ & $\begin{array}{l}\text { Kayalipark } \\
\text { Yayınları }\end{array}$ & $\begin{array}{c}\text { Ayşegül Sözen } \\
\text { Dağ }\end{array}$ & - & $\begin{array}{l}\text { Mümine } \\
\text { Yeşilmen }\end{array}$ & Ocak 2017 & 1.(Son Basım) & 78 \\
\hline K18 & Elimdeki Kelimeler & $\begin{array}{l}\text { Desen } \\
\text { Yaylnc1lk }\end{array}$ & $\begin{array}{l}\text { Benedicte } \\
\text { Gourdon }\end{array}$ & Özden Tuna & Malika Fouchier & Kasım 2011 & 1.(Son Basım) & 32 \\
\hline K19 & Farklı ama Aynı & YKY Yayıncilık & Feridun Oral & - & Feridun Oral & Ocak 2015 & $\begin{array}{l}\text { 4.(Son Basim) } \\
\text { Ocak } 2017\end{array}$ & 24 \\
\hline $\mathrm{K} 20$ & Kanatsız Arı Mu & Elma Yayınevi & $\begin{array}{l}\text { Ahmet Şerif } \\
\text { İzgören }\end{array}$ & - & Pervin Özcan & Şubat 2016 & $\begin{array}{l}\text { 2.(Son Basım) } \\
\text { Ağustos } 2016\end{array}$ & 35 \\
\hline
\end{tabular}




\begin{tabular}{|c|c|c|c|c|c|c|c|c|}
\hline K21 & Kısa Kulaklı Tavşancık & YKY Yayınlart & Julia Liu & $\begin{array}{l}\text { Çiğden } \\
\text { Kaplang1 }\end{array}$ & Leo Tang & Mart 2015 & $\begin{array}{l}\text { 3.(Son Basım) } \\
\text { Şubat } 2017\end{array}$ & 35 \\
\hline K22 & Kurşun Asker & Polat Kitapçıllk & - & - & Ercan Dinçer & - & 2015 & 16 \\
\hline K23 & Pembe Karga & YKY Yayınlar1 & Helga Bansch & Dürrin Tunç & $\begin{array}{l}\text { Süreyya } \\
\text { Erdoğan }\end{array}$ & Ocak 2017 & 1.(Son Basim) & 22 \\
\hline K24 & Şuşu, Can ve Dörtteker & Sev yayıncilik & $\begin{array}{l}\text { Yildıray } \\
\text { Karakiya }\end{array}$ & - & Başak Günaçan & Ağustos 2014 & $\begin{array}{l}\text { 2.(Son Basım) } \\
\text { Ocak } 2016\end{array}$ & 26 \\
\hline K25 & Tekerlekli Sandalye & Nar Yayıncllik & Bestami Yazgan & - & Kemal Yargic1 & Nisan 2013 & - & 16 \\
\hline K26 & Tek Gözlü Kedi & KÖK Yayıncilık & Serpil Ural & - & Serpil Ural & - & $\begin{array}{l}\text { 5.(Son Basım) } \\
\text { Aralık } 2009\end{array}$ & 16 \\
\hline K27 & Yapabilirim! & $\begin{array}{c}\text { TÜBİTAK } \\
\text { Yayınları }\end{array}$ & $\begin{array}{l}\text { Jeniffer Moore- } \\
\text { Mallinos }\end{array}$ & Ebru Kılıç & Marta Fabrega & Aralık 2008 & $\begin{array}{l}\text { 2.(Son Basım) } \\
\text { Ekim } 2011\end{array}$ & 31 \\
\hline
\end{tabular}

